\title{
Compressive Behaviour of RC Column with Fibre Reinforced Concrete Confined by CFRP Strips
}

\author{
A. M. Vasumathi, ${ }^{1}$ K. Rajkumar, ${ }^{2}$ and G. Ganesh Prabhu ${ }^{3}$ \\ ${ }^{1}$ Department of Civil Engineering, KLN College of Information Technology, Sivagangai, Tamil Nadu 630611, India \\ ${ }^{2}$ Department of Civil Engineering, SACS MAVMM Engineering College, Madurai, Tamil Nadu 625301, India \\ ${ }^{3}$ Department of Civil Engineering, Chungnam National University, Daejeon, Republic of Korea
}

Correspondence should be addressed to K. Rajkumar; rajstruct.engg@gmail.com and G. Ganesh Prabhu; gganeshlingesh@gmail.com

Received 24 May 2014; Revised 17 September 2014; Accepted 23 September 2014; Published 13 October 2014

Academic Editor: Liyuan Sheng

Copyright ( 92014 A. M. Vasumathi et al. This is an open access article distributed under the Creative Commons Attribution License, which permits unrestricted use, distribution, and reproduction in any medium, provided the original work is properly cited.

\begin{abstract}
The structural application of synthetic fibre reinforced concrete (FRC) has become widespread in the construction industry in order to satisfy the requirement of the earthquake resistant structures. Research conducted so far are focused on the structural behaviour of RC column externally confined with FRP composites, while studies are needed to address the behaviour of FRP strengthened $\mathrm{RC}$ column fabricated using fibre reinforced concrete. With the intention that the experimental investigation was carried out to evaluate the feasibility use of CFRP composite strips in strengthening of RC column made with fibre reinforced concrete. Circular synthetic Polypropylene fibre was used in the rate of $0.50 \%$ in the volume of concrete. CFRP strips having a width of $50 \mathrm{~mm}$ were used to confine the column and the experimental parameters were effective spacing between the CFRP strips (20 $\mathrm{mm}$ and $30 \mathrm{~mm}$ ) and the number of CFRP layers (one, two and three). The externally bonded CFRP strips counteract the lateral expansion of the concrete significantly by providing restraining effect and thus effect enhanced the stiffness of the column. The column strengthened with CFRP strips showed a maximum of $198.87 \%$ and $91.75 \%$ enhancement in axial deformation control and ultimate strength, respectively, compared to that of reference column. From the test results obtained, it is suggested that CFRP strips with the spacing of $20 \mathrm{~mm}$ and $30 \mathrm{~mm}$ can be used in strengthening of RC column made with FRC; however the column confined with $30 \mathrm{~mm}$ spacing provides an economical advantage compared to that of $20 \mathrm{~mm}$ spacing.
\end{abstract}

\section{Introduction}

Concrete is the widely used construction material throughout the world; however it completely losses the load carrying capacity, once the cracks/failure are initiated. In order to overcome these issues, inclusion of short fibers in concrete has been practiced and studied by various researchers [1-8]. The randomly oriented short fibres control the propagation of microcrack and improve the overall crack resistance of the concrete. In addition, the fibre reinforced concrete (FRC) behaves like a composite material and this behaviour is significantly different from the conventional concrete. Two kinds of fibres such as steel fibre and polypropylene fiber (PP fibre) are widely used in the construction industry due to the improved influence on the spalling behaviour of concrete. The research was performed on different types of FRC [1-17] and showed that the FRC has good mechanical properties such as compressive, tensile, and bending properties. Past few decades, FRC has been widely applied in different structural and nonstructural applications, including a column in tall structures, bridge piers, tunnels, and industrial floors and slabs, and where the toughness and crack strength is a major concern. However, in recent years, FRC structures have not been able to meet the current design standards due to the inadequate design and/or poor construction quality and also ageing of structures that is often reported. In addition, corrosion of steel exerts substantial tensile forces on the surrounding concrete and causes it to crack and spall off. Hence, these structures require armor to support the designed load, or even require renovation to resist possible higher loading. Over the past several decades, external strengthening using steel plates has been widely applied to improve the strength 
capacity of the RC column and, in addition, the effectiveness of this technique has been demonstrated through various strengthening applications. Even though the technique was successful in practice, it created some problems, including the addition of weight, corrosion of the steel plate, the need for skilled labour, and higher costs. In addition the research outcomes revealed that the bonding of linear steel jackets were ineffective in providing confinement pressure. In contrast, use of fibre reinforced polymer (FRP) composites for rehabilitation does not have any of these drawbacks and, moreover, can enable the upgrading of deteriorated members without significantly altering the appearance of the members. In addition, FRP composites are lightweight, durable, and resistant to corrosion and have high tensile strength, stiffness, and fatigue strength. Over the past several decades, extensive researches have been conducted on retrofitting/strengthening of RC structures using various FRP composites. Demers and Neale [18] performed an experimental investigation to evaluate the confinement effect of CFRP sheets on the behaviour of circular RC column. The test results of sixteen columns revealed that the FRP confinement considerably enhances the structural performance of the concrete columns, especially with regard to ductility. The test results of FRP strengthened $\mathrm{RC}$ circular columns under axial and/or eccentric loadings can be found in Seible et al. [19], Xiao and Ma [20], Mirmiran and Shahawy [21], Toutanji and Balaguru [22], and Teng and Lam [23]. The investigation conducted by Yaqub and Bailey [24] demonstrated that the load-carrying capacity of postheated columns can be restored up to the original level or greater than those of unheated columns. Punurai et al. [25] found that the lateral deflection of the RC slender columns subjected to combined axial load and biaxial bending can be reduced using CFRP composites, oriented in the longitudinal direction. In another study Siddiqui et al. [26] found that the externally bonded CFRP hoop wraps provide confinement to concrete and lateral support to the longitudinal fibers and thus increase the strength of the slender RC columns. Vincent and Ozbakkaloglu [27] studied the effect of fiber angle and specimen end condition on the axial compressive behavior of fiber reinforced polymer (FRP) confined concrete and the results revealed that the specimen performance is optimized when fibers are aligned in the hoop direction and the performance diminishes with decreasing fiber angle. In another study Vincent and Ozbakkaloglu [28] evaluated the influence of concrete compressive strength and confinement method on confined high and ultrahigh-strength concrete (HSC and UHSC) specimens. The test results indicated that the FRP confined HSC and UHSC exhibit highly ductile behavior; however, for the same normalized confinement pressures, axial performance of FRP confined concrete reduces as concrete strength increases. Wu et al. [29], Kusumawardaningsih and Hadi [30], Ozbakkaloglu and Lim [31], and Pham et al. [32] proposed a design method to evaluate the axial load strength of rectangular and square reinforced compression members confined with CFRP/GFRP jackets. Recently few researchers have performed a research on analytical and numerical modelling of FRP strengthened RC structures subjected to various loading [33-35].
The studies available so far are concerned with the behaviour of conventional RC column confined with various types of FRP composites and the results revealed that the FRP composites can be used to enhance the strength and stiffness of the structures. However, over the past few decades, the fabrication of structural components using FRC has become widespread. But, no experimental studies are available yet to demonstrate the influence of FRP composites in strengthening of RC column fabricated using fibre reinforced concrete (FRC). Therefore, studies are needed to address the behaviour of FRP strengthened RC column made with FRC. In order to address these issues, the investigation was carried out to evaluate the feasibility use of CFRP composite strips in strengthening of RC column fabricated using FRC. PP fibre was added in concrete in the range of $0.50 \%$ in volume of concrete, which was obtained from the test results. Totally, seven circular columns were fabricated using FRC. Among the seven columns, six columns were externally strengthened by CFRP composite strips having a constant width of $50 \mathrm{~mm}$ with two different parameters comprising spacing between the CFRP strips $(20 \mathrm{~mm}$ and $30 \mathrm{~mm})$ and number of CFRP layers (one, two, and three layers). All the columns were tested under axial compression until failure. The failure modes, axial stress-strain behaviour, ductility index, and ultimate strength of the strengthened FRC columns were discussed in a detailed manner.

\section{Material Properties}

2.1. Cement and Aggregates. Locally available ordinary/commercial Portland cement was used as a binding material in this study. According to IS 8112:2013 [36], the specific gravity of the cement was tested and the value obtained was about 3.13. Natural river sand passing through $4.75 \mathrm{~mm}$ was used as fine aggregate and crushed blue metal about $10 \mathrm{~mm}$ size was used as a coarse aggregate. The sieve analysis of both fine and coarse aggregates was carried out according to IS 2386(1):1963 [37] and the specific gravity [38] of the sand and the coarse aggregate was about 2.48 and 2.67 , respectively.

2.2. Steel Reinforcement. The commercial high yield strength deformed (HYSD) bars having a yield strength of $415 \mathrm{~N} / \mathrm{mm}^{2}$ was used as reinforcement. Six numbers of $8 \mathrm{~mm}$ diameter bars were used as a vertical/main reinforcement and the rings/stirrups were fabricated using $6 \mathrm{~mm}$ diameter bar.

2.3. CFRP Fabrics. A unidirectional carbon fibre called Sikawrap-230 C, which is fabricated by SIKA India Inc., was used in this study to strengthen the column. Carbon fibre was selected for its superior mechanical and durability properties. The stiffness and tensile strengths of the fibre were $230 \mathrm{kN} / \mathrm{mm}^{2}$ and $4300 \mathrm{~N} / \mathrm{mm}^{2}$, respectively provided by the manufacturer. The thickness of fibre was $0.131 \mathrm{~mm}$. It is a fabric type of fibre and can be tailored into any desired shape.

2.4. Matrix Material. An epoxy impregnation resin, called Sikadur-330 supplied by SIKA India Inc., was used in this study to make the effective bond between concrete and CFRP. 
It is a two-part system that includes resin and hardener, and the mixing ratio was $100: 25(\mathrm{~B}: \mathrm{H})$.

2.5. Polypropylene Fibre. Circular polypropylene fibre having a diameter and the length of $25 \mu \mathrm{m}$ and $40 \mathrm{~mm}$ was used in this study. The specific gravity of the fibre was about $0.98 \mathrm{~g} / \mathrm{cm}^{3}$ and the torsional resistibility was about $380 \mathrm{~N} / \mathrm{mm}^{2}$.

2.6. Concrete. According to IS 10262:2009 [39], concrete mix proportions were designed to achieve the strength of $25 \mathrm{~N} / \mathrm{mm}^{2}$ (M25). The mix proportion of the concrete was $1: 1.6: 2.9$ (cement: fine aggregate: coarse aggregate). A constant water to cement ratio (W/C) was followed for all mixtures, and the value was about 0.40 . A test was performed to determine the 28 days' compressive strength using $150 \mathrm{~mm} \times 150 \mathrm{~mm} \times 150 \mathrm{~mm}$ cubes. The average strength of the concrete obtained was about $36.5 \mathrm{~N} / \mathrm{mm}^{2}$.

\section{Specimen Fabrication}

A total of seven columns were fabricated with FRC and the concrete mixtures were prepared with the inclusion of PP fibre in the rate of $0.50 \%$ in volume of concrete. Among the seven columns, six columns were confined by $50 \mathrm{~mm}$ CFRP strips having the spacing of $20 \mathrm{~mm}$ and $30 \mathrm{~mm}$ with one, two, and three layers and the remaining one was reference column. Steel mould having a size of $125 \mathrm{~mm}$ diameter and $800 \mathrm{~mm}$ height was fabricated and the inside portion of the mould was thoroughly coated with oil to obtain a smooth surface. For all mixtures, cement, aggregates, and PP fibre were weighed in dry state and mixed together in 30 litre Omni Mixer in dry condition to enhance the dissipation action of PP. Then later, water was added in the dry mixture and the mixture was mixed together for 180 seconds. Steel reinforcement was prepared and then placed in the mould, with required cover. After that the mould was filled with concrete layer by layer and each layer of the concrete was effectively compacted by the needle vibrator. After 24 hours, the moulds were removed and the columns were allowed to membrane curing for 28 days. After curing, all the columns were subjected to sand blasting using coarse sand to roughen the surface. Before the columns were strengthened with FRP composites, acetone was used to clean the surface to remove the contaminated materials. Finally, the members were strengthened with CFRP composite strips with two different wrapping schemes, and the different spacings are shown in Figure 1. During wrapping, a steel roller was used in the direction of the fibre to remove the air gaps and excessive resin is shown in Figure 2.

\section{Experimental Setup}

All the columns were tested under axial in compression testing machine having a capacity of $2000 \mathrm{kN}$. The column member was placed on the supports, and care was taken to ensure that its centerline was exactly in line with the axis of the machine. The columns were instrumented to measure

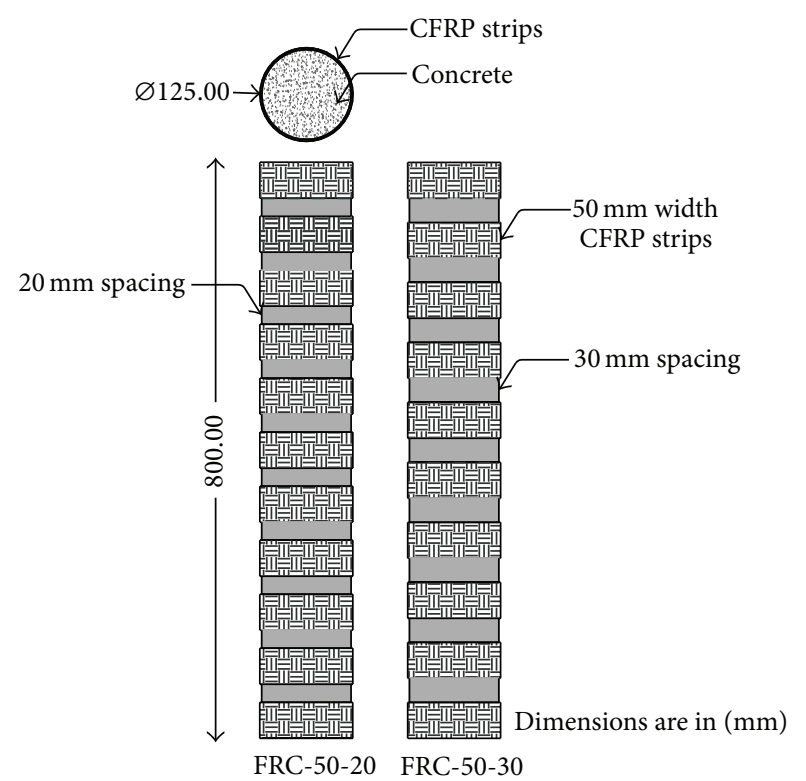

Figure 1: CFRP wrapping scheme.

the axial deformation using a linear voltage displacement transducer (LVDTs), and $2000 \mathrm{kN}$ load cell was used to monitor the load. Both load cell and LVDTs were connected to the 16-Channel Data Acquisition System to store the data. The load was applied to the columns using an electronic jack and they were tested to failure. The experimental observation recorded the nature of the failure, axial deformation, and ultimate load.

\section{Description of Mixtures}

To identify the specimens easily, the columns were designated with names such as FRC-CC, FRC-20-1, FRC-20-2, FRC20-3, FRC-30-1, FRC-30-2, and FRC-30-3. For example, the name of specimen FRC-30-2 specifies that the FRC column was strengthened by two (2) layers of $50 \mathrm{~mm}$ width CFRP strip with the spacing of $30 \mathrm{~mm}$. The control column is specified as FRC-CC.

\section{Results and Discussions}

6.1. Failure Modes. In the case of control column (FRC-CC), initially there was no cracking sound of concrete observed; in addition, the applied load was directly proportional to the deformation of the column. Loading further, cracks in concrete appeared at the supports of the column; in addition, the deformation of the column was increased with the constant load. Finally, the columns failed due to the shear and splitting failure of concrete observed on all four sides which occurred at the bottom of the column as shown in Figure 3. The inclusion of fibre prevented the spalling of the concrete; in addition, significant deformability was observed. In the case of column confined by $20 \mathrm{~mm}$ spacing of CFRP strips with one, two, and three layers (FRC-20-1, FRC-20-2 and FRC-20-3) initially cracking sound was observed due to 


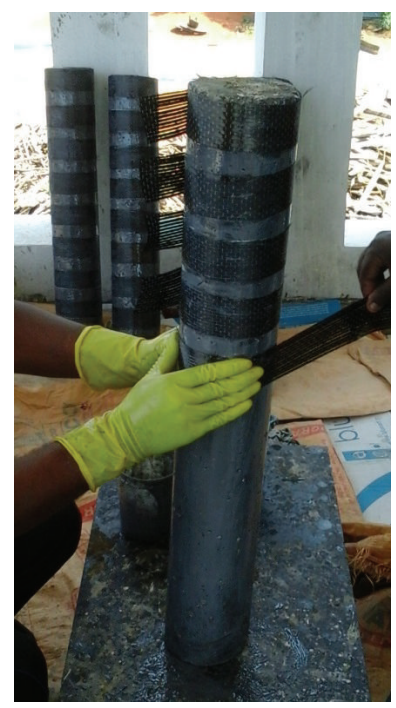

(a)

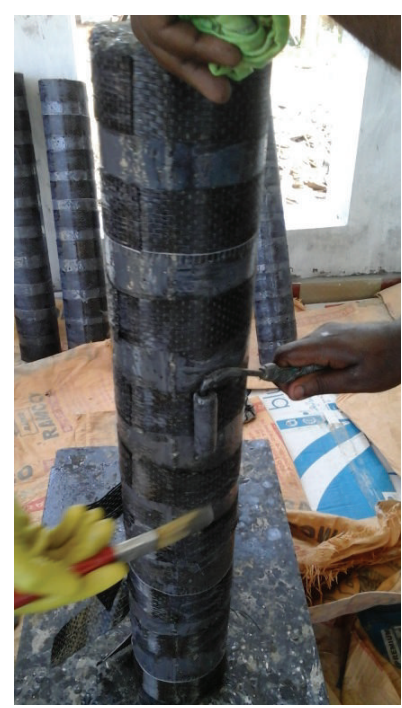

(b)

FIGURE 2: Bonding procedure: (a) bonding of CFRP strips and (b) removing the air gaps and excessive resin using steel roller.

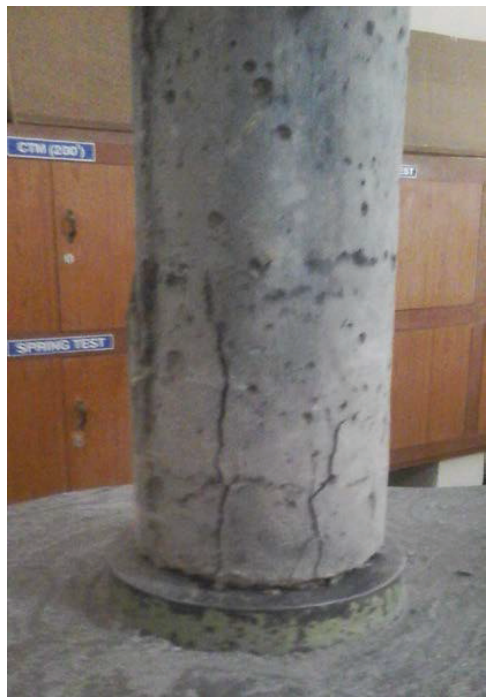

FIGURE 3: Failure mode of control column made with FRC concrete.

the crushing of resin; in addition, at the respective ultimate load of the control column, there were no cracks observed in the un-bonded concrete surface. The cracking sound of resin demonstrated that the CFRP strips restraint the poison's effect of the concrete by providing confining pressure. Loading further, all the columns failed due to the rupture of fibre followed by crushing of concrete as shown in Figure 4. This is a result of the fact that when the uniform pressure was applied on the top of the surface of the column, concrete expanded laterally; meanwhile CFRP layers in the outer limits provide restraining effect against the lateral deformation and they are subjected to tension in the hoop direction. When the CFRP reached its ultimate strain, rupture of CFRP occurred, followed by the crushing of concrete. When increasing the spacing of CFRP strips from $20 \mathrm{~mm}$ to $30 \mathrm{~mm}$, the columns strengthened by one and two layers of CFRP failed through rupture of fibre followed by crushing of concrete as shown in Figure 4. However, in the case of column strengthened with three layers of CFRP failed through crushing of concrete alone without any rupture of fibre observed in the unbonded area as shown in Figure 9. The failure mode is attributed to the debonding between the concrete and CFRP strips and may be due to the presence of air gaps and excessive resin. In all the columns except FRC-30-3, sudden drop off in load was observed at the peak stage due to the absence of confining pressure provided by the CFRP because of fibre rupture. In addition, it has been noted that no debonding of fibre was observed before ultimate load, and thus it was confirmed that there was a perfect bond between the concrete and CFRP.

6.2. Axial Stress-Strain Behaviour. The percentage of enhancement in the restraining effect against axial deformation is compared to the reference column and is summarized in Table 1. Figure 5 shows the stress-strain behaviour of all the columns. This research is aimed to evaluate the feasibility use of CFRP composite strips in the strengthening of FRC column members. As expected, the externally bonded CFRP composite strips effectively delayed the axial deformation of the column in both spacings by providing restraining effect and enhancing the buckling stress of the column. However, due to the immediate absence of the confining pressure provided by the CFRP, sudden fall in the curve was observed at the peak stage loading in all columns as shown in Figure 5. From Figure 5, it can be understood that, initially, the external bonding of CFRP strips with one layer does not show any significant effect on the deformation control; however, in higher loading it showed restraint against axial deformation and enhanced the buckling stress of the column. In the case of column confined with two and three layers, from 


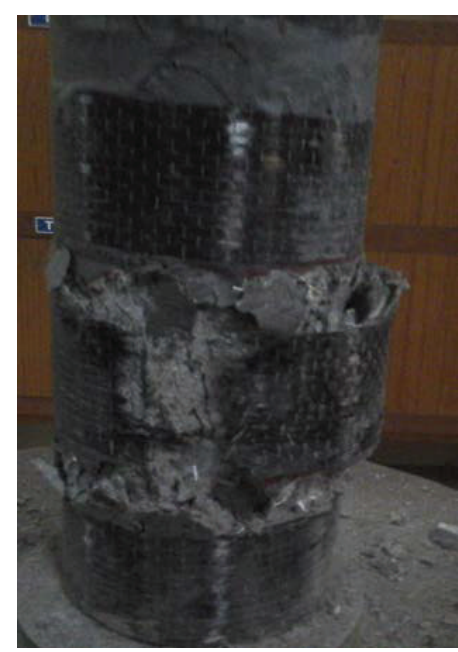

(a)

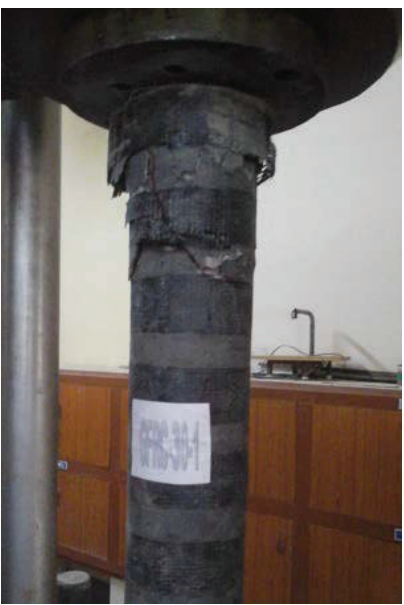

(d)

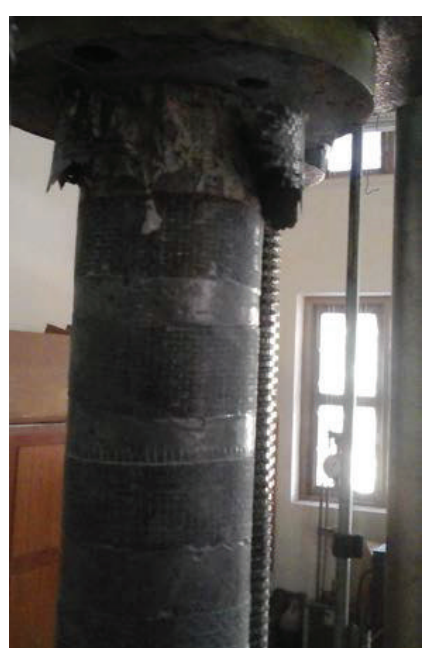

(b)

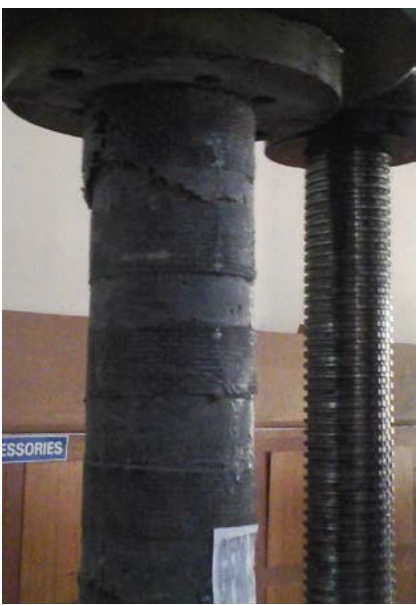

(e)

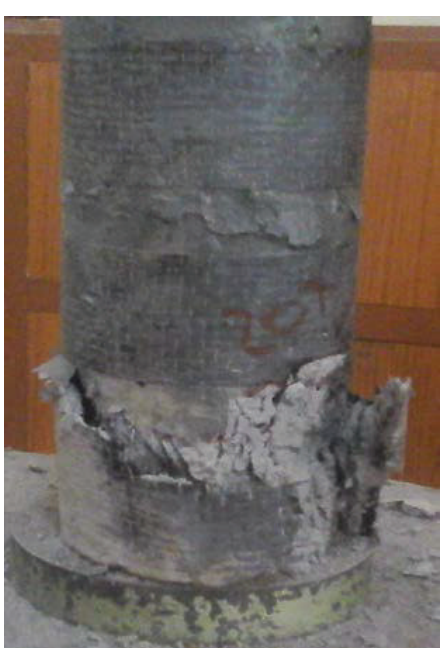

(c)

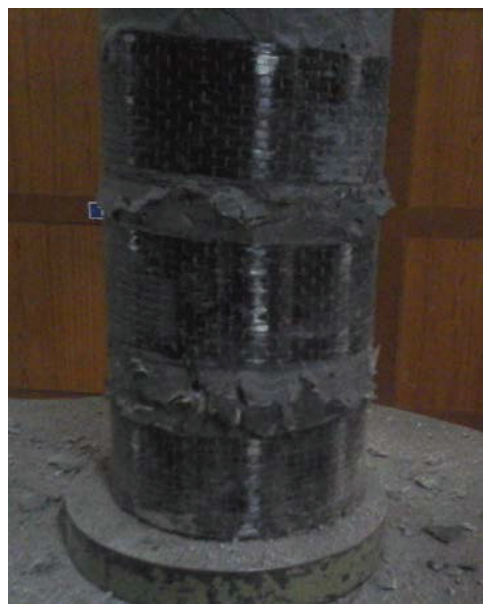

(f)

Figure 4: Failure mode of all strengthened columns (a) FRC-20-1, (b) FRC-20-2, (c) FRC-20-3, (d) FRC-30-1, (e) FRC-30-2, and (f) FRC-30-3.

TABLE 1: Experimental result of all specimens.

\begin{tabular}{|c|c|c|c|c|}
\hline Designation of columns & $\begin{array}{l}\text { Failure load } \\
\quad(\mathrm{kN})\end{array}$ & $\begin{array}{c}\% \text { of reduction in axial } \\
\text { deformation compared to } \\
\text { CC1 }\end{array}$ & $\begin{array}{l}\text { Ductility } \\
\mu_{\Delta}=\Delta / \Delta_{y}\end{array}$ & $\begin{array}{l}\% \text { of increase in axial } \\
\text { load carrying capacity }\end{array}$ \\
\hline$\overline{\text { FRC-CC }}$ & 279.12 & - & 1.271 & - \\
\hline FRC-20-1 & 356.33 & 10.236 & 1.272 & 27.59 \\
\hline FRC-20-2 & 421.82 & 121.052 & 1.362 & 50.89 \\
\hline FRC-20-3 & 535.29 & 198.872 & 1.392 & 91.75 \\
\hline FRC-30-1 & 354.36 & 6.870 & 1.252 & 26.88 \\
\hline FRC-30-2 & 400.73 & 104.878 & 1.323 & 43.36 \\
\hline FRC-30-3 & 493.22 & 170.967 & 1.371 & 76.70 \\
\hline
\end{tabular}

the initial stage, the CFRP strips significantly control the axial deformation and showed outperformed enhancement in buckling stress as shown in Figure 5. The increase in the number of CFRP layers enhances the composite plate thickness and as a result the restraining effect against axial deformation of the column has increased; however the enhancement was not proportional as shown in Figure 6.
Meanwhile the CFRP strip in the outer limits confine the concrete by providing confinement pressure and keep the concrete in a state of three-dimensional stress and as a result the strength capacity of the columns was increased significantly. The bond strength between the CFRP layers is directly proportional to the load transfer. If the resin lying between the two FRP layers starts to crush, a substantial 


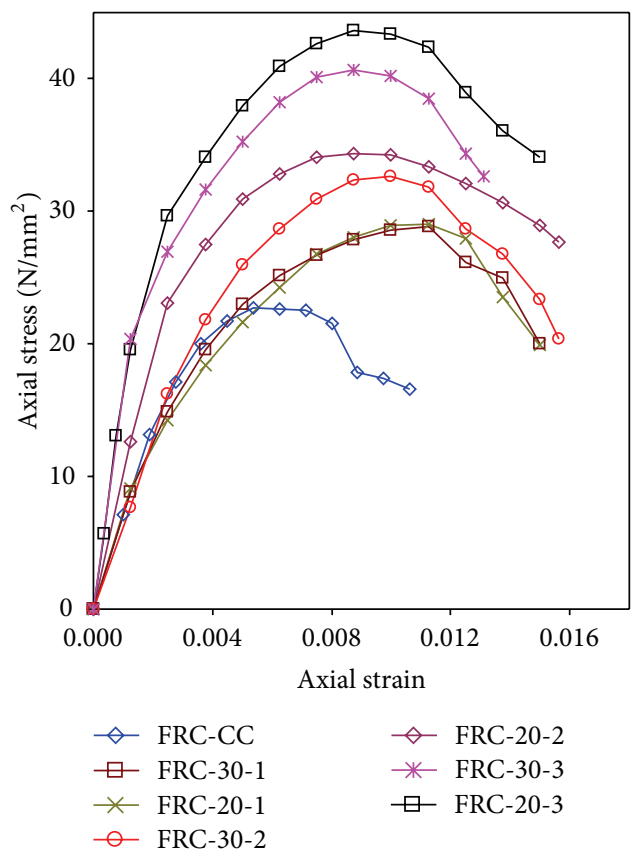

FIgURE 5: Axial stress-strain behaviour of all columns-comparison.

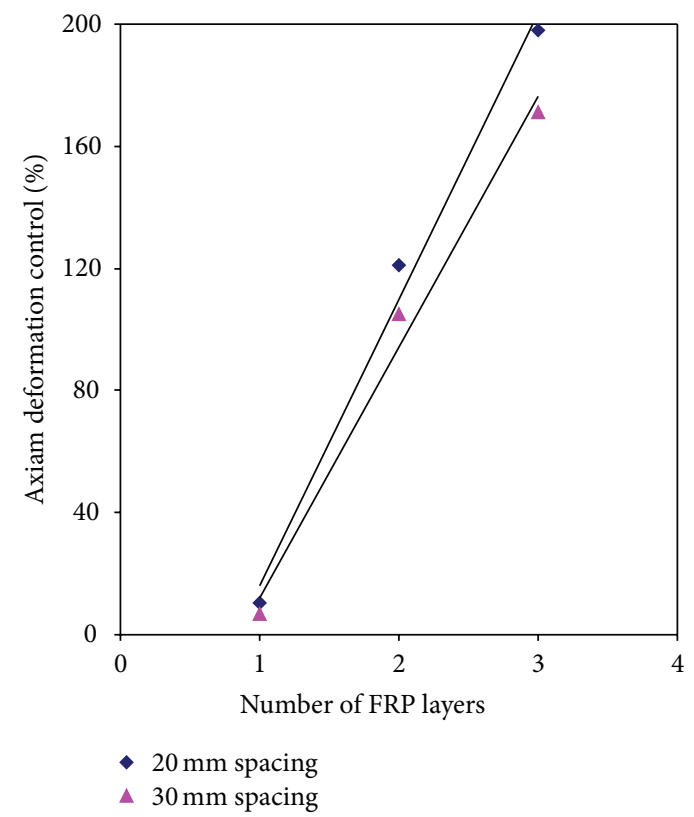

FIgURE 6: Correlation between axial deformation control and number of CFRP layers.

drop in load transfer will occur, the resulting confinement pressure provided by the next FRP layer will be automatically decreased, and as a result, nonlinearity in axial deformation control can be observed. At the respective failure load of FRC-CC, the columns FRC-20-1, FRC-20-2, and FRC-203 showed an axial deformation of $3.81 \mathrm{~mm}, 1.92 \mathrm{~mm}$, and $1.41 \mathrm{~mm}$, respectively, which is $10.23 \%, 121.05 \%$, and $198.87 \%$, respectively. However, the column FRC-20-3 enhanced its restraining effect by $366.32 \%$ and $128.57 \%$ when compared to the columns FRC-20-1 and FRC-20-2, respectively; in addition the axial deformation of the column was $1.93 \mathrm{~mm}$ and $3.062 \mathrm{~mm}$ at the respective failure load of FRC-20-1 and FRC-20-2, respectively. The studies conducted previously $[40,41]$ reported that the RC column made with conventional concrete confined with three layers CFRP composites showed the average axial deformation control of $172.24 \%$ compared to the reference column. However, it is interesting to note that the FRC column confined with three layers of CFRP strips showed the restraint enhancement of $198.87 \%$, compared to the reference column. This enhancement is attributed to the high flexural toughness and the postcracking behaviour of the concrete due to the inclusion of the fibre. In the hardened state, the fibres were effectively bonded to the concrete; they assist in controlling the propagation of microcracks present in the matrix by stress transfer and delay the cracks coalescence and lead to increase in the tensile strength of the concrete. From this observation, it is concluded that the creation of restraint effect against axial deformation of the column may be dependent upon the type of concrete used to fabricate.

When lifting up the spacing of the CFRP strips from $20 \mathrm{~mm}$ to $30 \mathrm{~mm}$, the columns were shown an above similar behavior; however the loss in restraining effect against axial deformation was observed compared to that of column confined with $20 \mathrm{~mm}$ spacing. From Figure 5, it can be observed that the column confined with two and three layers showed a profound effect on the axial deformation control, however it enhances the buckling stress of the column later. The columns FRC-30-1 and FRC-30-2 showed an axial deformation in the range of $3.93 \mathrm{~mm}$ and $2.05 \mathrm{~mm}$, respectively, at the respective failure load of FRC-CC, which is $6.87 \%$ and $104.87 \%$, respectively, lower than that of FRC-CC. The decrease in restraining effect against axial deformation may be due to the increase in the spacing between the CFRP strips led to the reduction in confining pressure exerted by the CFRP strips. However, the column FRC-30-3 showed an enhancement in deformation control from the initial stage and enhanced its axial deformation control by $170.96 \%$ compared to that of FRC-CC. Figure 5 indicates that the restraint in axial deformation of the columns increases with the increase in the number of layers; furthermore, the enhancement of buckling stress was not proportional (Figure 6) and this outcome is fairly in agreement with the column confined with $20 \mathrm{~mm}$ spacing.

From Figure 5, it can be understood that the restraining effect against axial deformation of the column decreased with the increase in the spacing between the CFRP strips, due to the decrease in the circumferential confining pressure provided by the CFRP composites. In comparison to column FRC-30-1, the column FRC-20-1 increased its restraining effect by $12.5 \%$; in addition, the column FRC-20-2 showed the axial deformation of $5 \mathrm{~mm}$ at the respective failure load of FRC-30-2, which is $61.20 \%$ lower than that of FRC-302. The column FRC-20-3 showed the gain in axial deformation control of $40.25 \%$ compared to the column FRC30-3. However, from Figure 5, it is interesting to note that the stress-strain behaviour of the column confined with $30 \mathrm{~mm}$ spacing is relatively similar to the column confined 


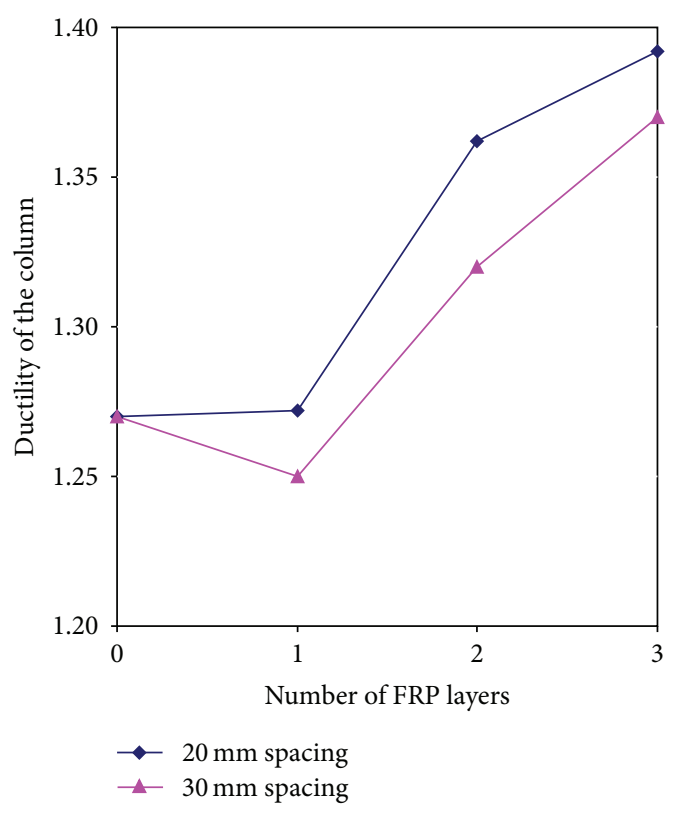

Figure 7: Ductility behaviour of all columns-comparison.

with $20 \mathrm{~mm}$ spacing; in addition, the columns confined with $20 \mathrm{~mm}$ spacing enhanced their restraining effect average of $37.58 \%$, compared to the columns confined with $30 \mathrm{~mm}$ spacing, and this difference is not much higher. It is suggested that the CFRP strips with a spacing of $20 \mathrm{~mm}$ and $30 \mathrm{~mm}$ can be used for strengthening of RC column made with FRC concrete; however the column confined with $30 \mathrm{~mm}$ spacing provides an economical advantage when compared to the $20 \mathrm{~mm}$ spacing.

6.3. Ductility. The ductility of the FRP confined column is the important structural property due to the rupture failure mode of the FRP composites. So that the ductility of the reference and CFRP strengthened columns was calculated based on (1), proposed by Kusumawardaningsih and Hadi [30]. Where $\mu_{\Delta}$ is the ductility of the column and $\Delta$ is the axial deformation of the column, when the load falls to $85 \%$ of the ultimate load, $\Delta_{y}$ is the deformation at yield load of the column. Consider

$$
\mu_{\Delta}=\frac{\Delta}{\Delta_{y}} .
$$

From Figure 7, it can be understood that the presence of CFRP strips enhances the ductility performance of the column; however, the enhancement was not significantly higher. The columns confined with three layers in both spacing showed the most beneficial effect on the ductility response when compared to the column confined with one and two layers. The reason is attributed to keeping the concrete in a state of three-dimensional stress by providing more confining pressure. The columns FRC-20-3 and FRC$30-3$ showed a ductility value of 1.392 and 1.371, respectively, which is $9.62 \%$ and $7.87 \%$ higher than the FRC-CC. It is interesting to note that the ductility of the column was decreased with the increase in the spacing between the CFRP

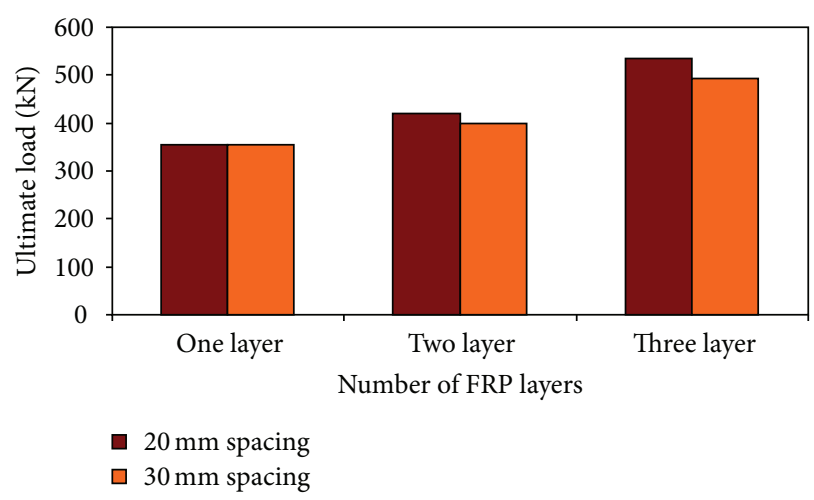

FIGURE 8: Ultimate strength of all columns-comparison.

strips due to the loss in confinement pressure. It is suggested that the CFRP material can be used as a strengthening material in strengthening of RC column made with FRC without affecting the ductility performance.

6.4. Axial Load Carrying Capacity. The measured ultimate strength of all the strengthened columns and their enhancements in strength compared to the reference column is presented in Table 1. This research is aimed to improve the strength capacity of the FRC column using externally bonded CFRP composite strips. As expected, the load carrying capacity of the column increased significantly. The columns FRC-20-1, FRC-20-2 and FRC-20-3 enhanced their load carrying capacity by $27.59 \%, 50.89 \%$ and $91.75 \%$, respectively, compared to the reference column. In a similar manner, the columns FRC C-30-1, FRC C-30-2, and FRC C-320-3 showed $26.88 \%, 43.36 \%$, and $76.70 \%$ increase in the load carrying capacity as shown in Figure 8 . This is a result of the fact that when the column was subjected to axial load, the concrete core start to expand laterally; meanwhile the CFRP strip layers in the outer limits confine the concrete by providing confinement pressure and keep the concrete in a state of three-dimensional stress and as a result the strength capacity of the columns was increased significantly. The past few researches $[40,41]$ that have been conducted on conventional RC column observed that the external bonding of three layers CFRP composites enhanced the load carrying capacity of the column by $71 \%$, when compared to the unstrengthened column. Nevertheless, the FRC column confined with CFRP strips increases their ultimate strength of maximum $91.75 \%$, when compared to the reference column. As discussed earlier, the strength enhancement is due to the increased flexural toughness and the postcracking behaviour of the concrete due to the inclusion of the fibre. It is interesting to note that the strength capacity of the columns was increased with the increases in the number of layers; however the enhancement was not proportional as shown in Figure 9. This could be attributed to the crushing failure of resin between the CFRP composite strips. The strength capacity of the column FRC20-3 was increased by $50.28 \%$ and $27.07 \%$ compared to that of columns FRC-20-1 and FRC-20-2, respectively, and also the column FRC-30-3 showed $39.26 \%$ and $23.25 \%$ increase in 


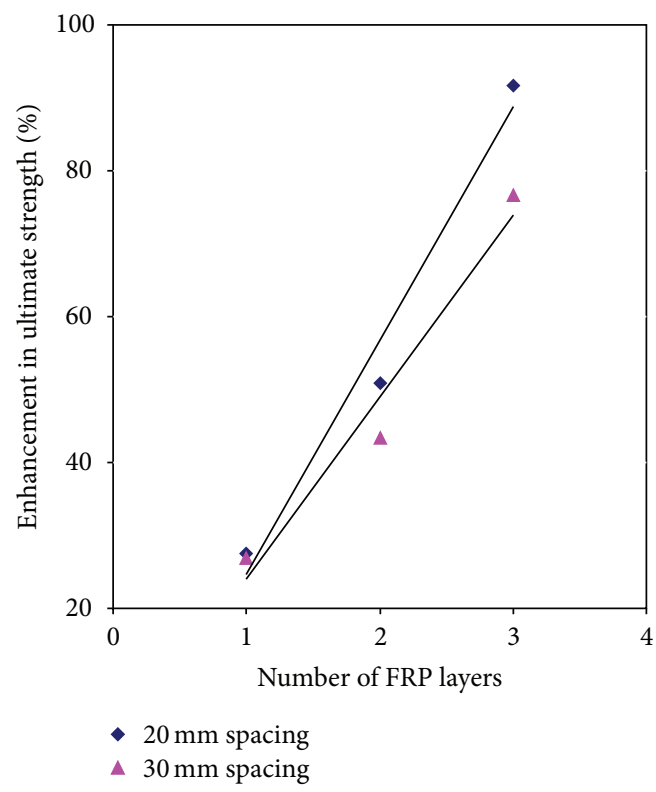

FIGURE 9: Correlation between enhancement in ultimate strength and number of CFRP layers.

the load carrying capacity when compared to the column FRC-30-1 and FRC-30-2, respectively as shown in Figure 8. From Figure 8, it can be understood that the increase in the spacing between the CFRP strips decreases the load carrying capacity of the column; however, the difference is not relatively high. In comparison with column confined with $20 \mathrm{~mm}$ spacing, the column confined with $30 \mathrm{~mm}$ spacing showed the average difference in strength of $4.60 \%$, and this difference is not relatively high. From the above results it is concluded that the strength capacity of the column depends upon the type of concrete used to fabricate and spacing between the CFRP strips. It is suggested that the CFRP strips having a spacing of $20 \mathrm{~mm}$ and $30 \mathrm{~mm}$ can be used in strengthening to enhance the strength capacity of the RC column made with FRC concrete under axial compression.

\section{Conclusion}

The feasibility of using CFRP composite strips as an upgrading material for FRC columns under axial compression was investigated. The experimental parameters were effective spacing between the FRP strips and number of CFRP layers. Based on the results obtained, the following conclusions were made.

(i) The external confinement provided by the CFRP composite strips in both spacing effectively control the Poisson effects of the concrete by providing confinement pressure and they failed by rupture of fibres followed by the crushing of concrete and this failure mode and led to the conclusion that there is a perfect bond between concrete and CFRP. (ii) The restraining effect provided by the CFRP strips in both spacing significantly reduced the axial deformation of the column and the formation of restraining effect was increased with the increase in the number of layers. The columns FRC-20-3 and FRC-30-3 showed a $198.87 \%$ and $170.96 \%$ enhancement, respectively, in restraining effect against axial deformation compared to the FRC-CC.

(iii) The presence of CFRP strips enhances the ductility performance of the column; the column confined with three layers in both spacing was especially higher.

(iv) The CFRP strips significantly prevent the Poisson effect of the concrete and keep the concrete in a state of three-dimensional stresse by providing confinement pressure and thus effectively enhance the load carrying capacity of the columns. In comparison with reference column, the columns FRC-20-3 and FRC30-3 enhanced their strength capacity by $91.75 \%$ and $76.70 \%$, respectively.

(v) The increased flexural toughness and the postcracking behaviour of the FRC showed better enhancement in strength capacity of FRP confined RC column when compared to the conventional RC column bonded with FRP composites.

(vi) It is suggested that CFRP strips having a spacing of $20 \mathrm{~mm}$ and $30 \mathrm{~mm}$ can be used in strengthening to enhance the strength capacity of the RC column made with FRC concrete under axial compression.

\section{Conflict of Interests}

The authors declare that there is no conflict of interests regarding the publication of this paper.

\section{References}

[1] B. E. Barragán, R. Gettu, M. A. Martín, and R. L. Zerbino, "Uniaxial tension test for steel fibre reinforced concrete-a parametric study," Cement and Concrete Composites, vol. 25, no. 7, pp. 767-777, 2003.

[2] M. K. Lee and B. I. G. Barr, "Strength and fracture properties of industrially prepared steel fibre reinforced concrete," Cement and Concrete Composites, vol. 25, no. 3, pp. 321-332, 2003.

[3] A. R. Khaloo and M. Afshari, "Flexural behaviour of small steel fibre reinforced concrete slabs," Cement and Concrete Composites, vol. 27, no. 1, pp. 141-149, 2005.

[4] L. G. Sorelli, A. Meda, and G. A. Plizzari, "Steel fiber concrete slabs on ground: a structural matter," ACI Structural Journal, vol. 103, no. 4, pp. 551-558, 2006.

[5] C. X. Qian and P. Stroeven, "Development of hybrid polypropylene-steel fibre-reinforced concrete," Cement and Concrete Research, vol. 30, no. 1, pp. 63-69, 2000.

[6] R. S. Olivito and F. A. Zuccarello, "An experimental study on the tensile strength of steel fiber reinforced concrete," Composites Part B: Engineering, vol. 41, no. 3, pp. 246-255, 2010. 
[7] S. P. Yap, U. J. Alengaram, and M. Z. Jumaat, "Enhancement of mechanical properties in polypropylene- and nylon-fibre reinforced oil palm shell concrete," Materials and Design, vol. 49, pp. 1034-1041, 2013.

[8] S. Tapkin, "The effect of polypropylene fibers on asphalt performance," Building and Environment, vol. 43, no. 6, pp. 1065-1071, 2008.

[9] H. Mazaheripour, S. Ghanbarpour, S. H. Mirmoradi, and I. Hosseinpour, "The effect of polypropylene fibers on the properties of fresh and hardened lightweight self-compacting concrete," Construction and Building Materials, vol. 25, no. 1, pp. 351-358, 2011.

[10] Y. Ding, F. Zhang, F. Torgal, and Y. Zhang, "Shear behaviour of steel fibre reinforced self-consolidating concrete beams based on the modified compression field theory," Composite Structures, vol. 94, no. 8, pp. 2440-2449, 2012.

[11] L. Ferrara, P. Bamonte, A. Caverzan, A. Musa, and I. Sanal, "A comprehensive methodology to test the performance of steel fibre reinforced self-compacting concrete (SFR-SCC)," Construction and Building Materials, vol. 37, pp. 406-424, 2012.

[12] S. Kakooei, H. M. Akil, M. Jamshidi, and J. Rouhi, "The effects of polypropylene fibers on the properties of reinforced concrete structures," Construction and Building Materials, vol. 27, no. 1, pp. 73-77, 2012.

[13] J. Michels, R. Christen, and D. Waldmann, "Experimental and numerical investigation on postcracking behavior of steel fiber reinforced concrete," Engineering Fracture Mechanics, vol. 98, no. 1, pp. 326-349, 2013.

[14] A. M. López-Buendía, M. D. Romero-Sánchez, V. Climent, and C. Guillem, "Surface treated polypropylene (PP) fibres for reinforced concrete," Cement and Concrete Research, vol. 54, pp. 29-35, 2013.

[15] O. Kayali, M. Haque, and B. Zhu, "Some characteristics of high strength fiber reinforced lightweight aggregate concrete," Cement \& Concrete Composites, vol. 25, no. 2, pp. 207-213, 2003.

[16] Z. Peng and L. Qing-Fu, "Experiment and study on tensile strength of polypropylene fiber reinforced cement stabilized macadam," Highway, 2008.

[17] L. Zhang, X. Wang, and G. Zheng, "Effect of polypropylene fibers on the strength and elastic modulus of soil-cement," in Geosynthetics in Civil and Environmental Engineering, pp. 386391, Springer, Berlin, Germany, 2009.

[18] M. Demers and K. W. Neale, "Confinement of reinforced concrete columns with fibre-reinforced composite sheets-an experimental study," Canadian Journal of Civil Engineering, vol. 26, no. 2, pp. 226-241, 1999.

[19] F. Seible, M. J. N. Priestley, G. A. Hegender, and D. Innamorato, "Seismic retrofit of RC columns with continuous carbon fiber jackets," Journal of Composites for Construction, vol. 1, no. 2, pp. 52-62, 1997.

[20] Y. Xiao and R. Ma, "Seismic retrofit of RC circular columns using prefabricated composite jacketing," Journal of Structural Engineering, vol. 123, no. 10, pp. 1357-1364, 1997.

[21] A. Mirmiran and M. Shahawy, "Behavior of concrete columns confined by fiber composites," Journal of Structural Engineering, vol. 123, no. 5, pp. 583-590, 1997.

[22] H. Toutanji and P. Balaguru, "Durability characteristics of concrete columns wrapped with FRP tow sheets," Journal of Materials in Civil Engineering, vol. 10, no. 1, pp. 52-57, 1998.
[23] J. G. Teng and L. Lam, "Compressive behavior of CFRPconfined elliptical concrete columns," Journal of Structural Engineering, vol. 128, no. 12, pp. 1535-1543, 2002.

[24] M. Yaqub and C. G. Bailey, "Repair of fire damaged circular reinforced concrete columns with FRP composites," Construction and Building Materials, vol. 25, no. 1, pp. 359-370, 2011.

[25] W. Punurai, C.-T. T. Hsu, S. Punurai, and J. Chen, "Biaxially loaded RC slender columns strengthened by CFRP composite fabrics," Engineering Structures, vol. 46, pp. 311-321, 2013.

[26] N. A. Siddiqui, S. H. Alsayed, Y. A. Al- Salloum, R. A. Iqbal, and H. Abbas, "Experimental investigation of slender circular RC columns strengthened with FRP composites," Construction and Building Materials, vol. 69, pp. 323-334, 2014.

[27] T. Vincent and T. Ozbakkaloglu, "Influence of fiber orientation and specimen end condition on axial compressive behavior of FRP-confined concrete," Construction and Building Materials, vol. 47, pp. 814-826, 2013.

[28] T. Vincent and T. Ozbakkaloglu, "Influence of concrete strength and confinement method on axial compressive behavior of FRP confined high- and ultra high-strength concrete," Composites Part B: Engineering, vol. 50, pp. 413-428, 2013.

[29] G. Wu, Z. S. Wu, and Z. T. Lü, "Design-oriented stress-strain model for concrete prisms confined with FRP composites," Construction and Building Materials, vol. 21, no. 5, pp. 1107-1121, 2007.

[30] Y. Kusumawardaningsih and M. N. S. Hadi, "Comparative behaviour of hollow columns confined with FRP composites," Composite Structures, vol. 93, no. 1, pp. 198-205, 2010.

[31] T. Ozbakkaloglu and J. C. Lim, "Axial compressive behavior of FRP-confined concrete: experimental test database and a new design-oriented model," Composites Part B: Engineering, vol. 55, pp. 607-634, 2013.

[32] T. M. Pham, L. V. Doan, and M. N. S. Hadi, "Strengthening square reinforced concrete columns by circularisation and FRP confinement," Construction and Building Materials, vol. 49, pp. 490-499, 2013.

[33] B. Hu, J.-G. Wang, and G.-Q. Li, "Numerical simulation and strength models of FRP-wrapped reinforced concrete columns under eccentric loading," Construction and Building Materials, vol. 25, no. 5, pp. 2751-2763, 2011.

[34] G. P. Lignola, F. Nardone, A. Prota, and G. Manfredi, "Analytical model for the effective strain in FRP-wrapped circular RC columns," Composites Part B, vol. 43, no. 8, pp. 3208-3218, 2012.

[35] X. Zhao, X.-J. He, S. Yan, and N. P. Anh, "Computational and simulation analysis of pull-out fiber reinforced concrete," Advances in Materials Science and Engineering, vol. 2014, Article ID 576052, 7 pages, 2014.

[36] IS8112:2013, Ordinary Portland Cement, 43 Grade-Specification, Bureau of Indian Standards, New Delhi, India, 2013.

[37] IS 2386(Part 1), Methods of Test for Aggregates for Concrete: Part 1 Particle Size and Shape, Bureau of Indian Standards, New Delhi, India, 1963.

[38] IS 2386-3, Methods of Test for Aggregates for Concrete: Part 3 Specific Gravity, Density, Voids, Absorption and Bulking, Bureau of Indian Standards, New Delhi, India, 1963.

[39] Bureau of Indian Standards, "Guidelines for concrete mix proportioning," IS 10262:2009, Bureau of Indian Standards, New Delhi, India, 2009. 
[40] T. W. Park, U. J. Na, L. Chung, and M. Q. Feng, "Compressive behavior of concrete cylinders confined by narrow strips of CFRP with spacing," Composites Part B: Engineering, vol. 39, no. 7-8, pp. 1093-1103, 2008.

[41] H. Bouchelaghem, A. Bezazi, and F. Scarpa, "Compressive behaviour of concrete cylindrical FRP-confined columns subjected to a new sequential loading technique," Composites Part B: Engineering, vol. 42, no. 7, pp. 1987-1993, 2011. 

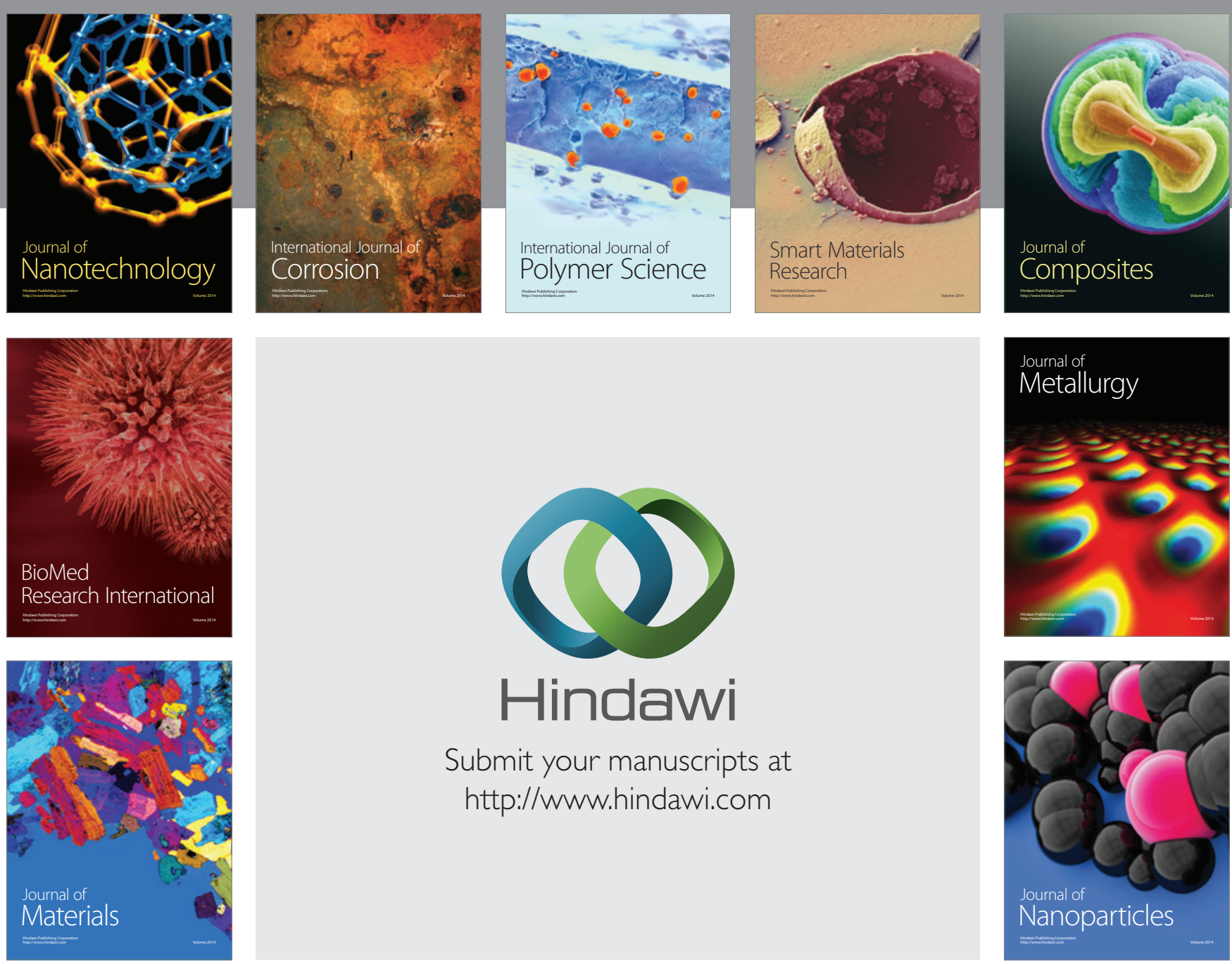

Submit your manuscripts at http://www.hindawi.com
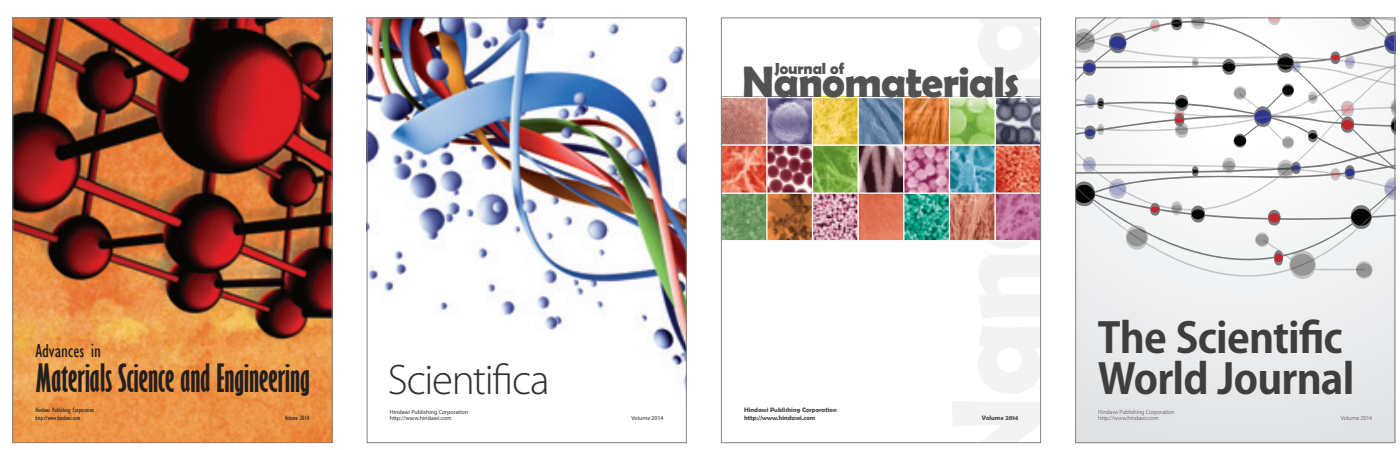

\section{The Scientific World Journal}
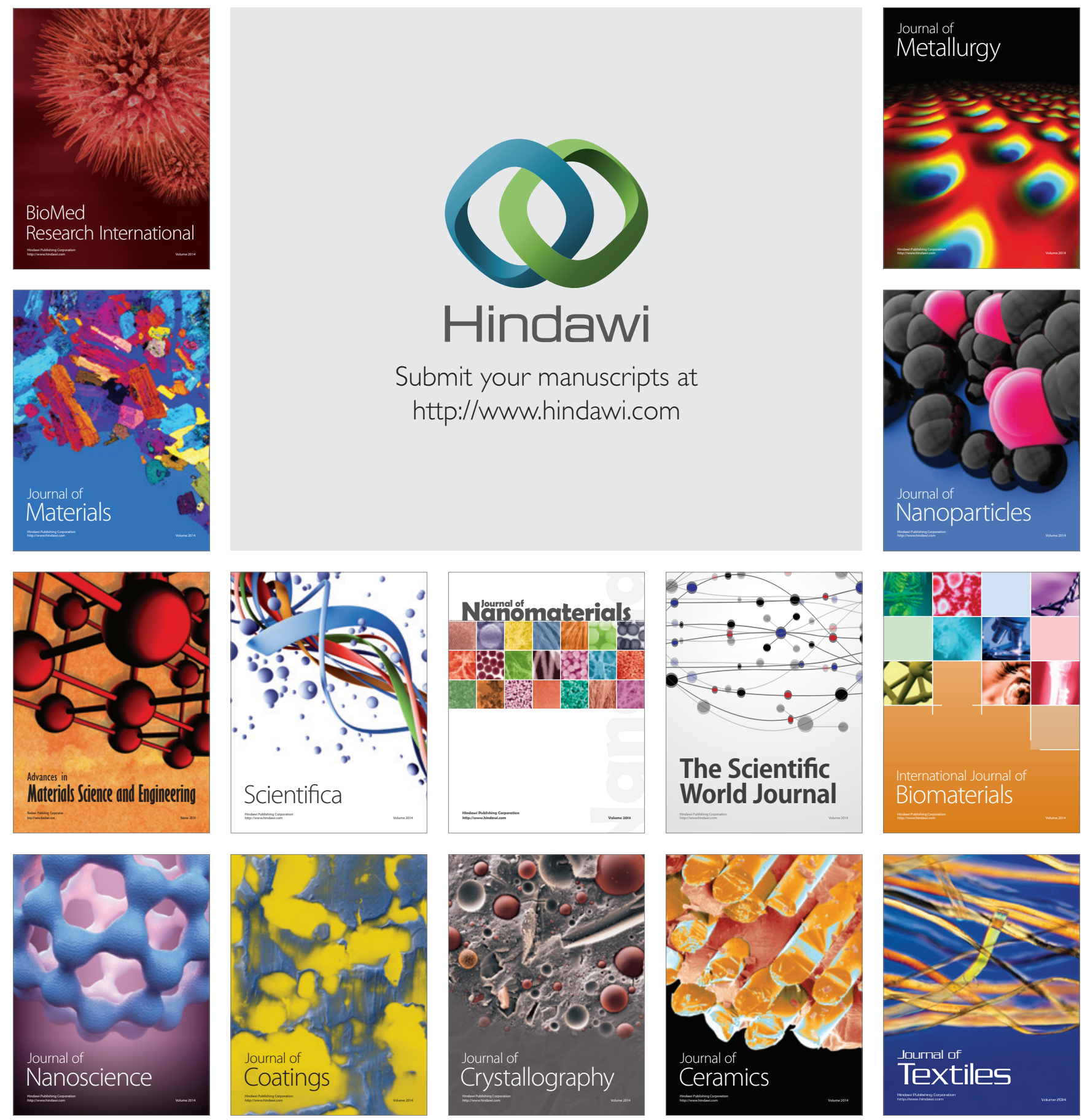